\title{
Correction to: The influence of ubiquitous connectivity, trust, personality and generational effects on mobile tourism purchases
}

\section{Roberto Pessoa de Queiroz Falcao ${ }^{1,2}\left(D_{0}\right.$. Jorge Brantes Ferreira ${ }^{2}$. Murilo Carrazedo Marques da Costa Filho ${ }^{2}$}

Published online: 11 November 2019

(c) Springer-Verlag GmbH Germany, part of Springer Nature 2019

\section{Correction to: Information Technology \& Tourism https://doi.org/10.1007/s40558-019-00154-1}

Dear Readers,

In the originally published version of this article, one of the names of the co-authors was not fully reproduced.

It should read as follows:

The name of the co-author "Murilo Carrazedo" is completely "Murilo Carrazedo Marques da Costa Filho".

We apologize for this mistake.

The original article has been corrected.

The original article can be found online at https://doi.org/10.1007/s40558-019-00154-1.

Roberto Pessoa de Queiroz Falcao

robertopqfalcao@gmail.com

1 Universidade Federal Fluminense, PPGE, Av. Visconde Do Rio Branco, 576-592, Centro, Niterói, RJ 24020-005, Brazil

2 Pontifícia Universidade Católica, IAG, R. Marquês de São Vicente, 225, Gávea, Rio de Janeiro, RJ 22451-900, Brazil 